Virginia Commonwealth University VCU Scholars Compass

Biology and Medicine Through Mathematics

Conference

May 20th, 4:00 PM - 4:30 PM

\title{
Influence of Concurrency, Partner Choice, and Viral Suppression on Racial Disparity in the Prevalence of HIV Infected Women
}

Katharine Gurski

Howard University, kgurski@howard.edu

Kathleen Hoffman

University of Maryland Baltimore County, khoffman@umbc.edu

Follow this and additional works at: http://scholarscompass.vcu.edu/bamm

Part of the Applied Mathematics Commons

http://scholarscompass.vcu.edu/bamm/2016/May20/10

This Event is brought to you for free and open access by the Dept. of Mathematics and Applied Mathematics at VCU Scholars Compass. It has been accepted for inclusion in Biology and Medicine Through Mathematics Conference by an authorized administrator of VCU Scholars Compass. For more information, please contact libcompass@vcu.edu. 
Influence of Concurrency, Partner Choice, and Viral Suppression on Racial Disparity in the Prevalence of HIV Infected Women

\section{K.F. Gurski, K.A. Hoffman}

Abstract: We present a mathematical model of the transmission of HIV through sexual contact in a population stratified by sexual behavior and race/ethnicity. The model also includes the effect of concurrency through the force of infection term, variations in population mixing (partner choice), and non-uniform Highly Active Anti-Retroviral Treatment (HAART) leading to viral suppression. We use this mathematical model to understand the non-uniform spread of HIV in women who were infected through heterosexual contact. Numerical simulations of the reproduction number as a function of concurrency, viral suppression level, and mixing show a reservoir of disease present in both heterosexual and MSM populations. Statistical analysis of parameter values shows that viral suppression level, mixing and progression to AIDS without viral suppression have a strong correlation (either positive or negative) with the number of HIV positive women. Concurrency and assortative mixing are shown to be essential to reproduce infection levels in women, as reported by 2010 data from the Center for Disease Control (CDC). 